\title{
COLLABORATION IN SOUTH AFRICAN ENGINEERING RESEARCH
}

\author{
R. Sooryamoorthy \\ Sociology Programme \\ University of KwaZulu-Natal, South Africa \\ sooryamoorthyr@ukzn.ac.za
}

\begin{abstract}
The production of scientific publications in engineering in South Africa has expanded over the last three decades. Because engineering is an important science, this expansion has implications for the growth and development of the economy. Drawing on a sample range of years of the publications stored in the ISI Web of Knowledge, the engineering publications of South Africans for a 30-year period from 1975-2005 are analysed. This analysis shows that the production of scientific publications in engineering by South African researchers has increased during the analysed period; that the number of researchers per publication has grown; that the number of countries collaborating with South Africa has increased; and that the number of sole-authored papers has decreased. Domestic collaboration (between researchers within South Africa) has decreased, while international collaboration has grown considerably. The key objective of the paper is to find out whether the production of publications is related to the level of collaboration, and to see how collaboration can be regressed from other known variables. It is clear from the study that collaboration is a decisive factor in the production of scientific publications in engineering in South Africa.
\end{abstract}

\section{OPSOMMING}

Die produksie van wetenskaplike publikasies in ingenieurswese in Suid-Afrika het oor die afgelope drie dekades toegeneem. Aangesien ingenieurswese ' $n$ belangrike wetenskap is, beïnvloed dié toename die groei en ontwikkeling van die ekonomie. Deur na ' $n$ monster van voormalige publikasies op die "ISI Web of Science" te kyk, is die publikasies in ingenieurswese deur Suid-Afrikaners oor ' $\mathrm{n} 30$ jaar periode van 1975-2005 geanaliseer. Die analise toon dat die produksie van wetenskaplike publikasies in ingenieurswese deur SuidAfrikaanse navorsers toegeneem het oor dié tydperk; dat die aantal navorsers per publikasie gegroei het; dat daar ' $\mathrm{n}$ toename was in die hoeveelheid lande wat met Suid-Afrika saamgewerk het; en dat die aantal artikels van enkelouteurs verminder het. Plaaslike samewerking (tussen Suid-Afrikaanse navorsers) het afgeneem, maar internasionale samewerking het aansienlik toegeneem. Die hoofdoelwit van die artikel is om te bepaal of die produksie van publikasies verband hou met die vlak van samewerking, en om vas te stel hoe samewerking vanaf ander bekende veranderlikes terugbereken kan word. Uit die studie blyk dit duidelik dat samewerking ' $n$ beslissende faktor is ten opsigte van die produksie van wetenskaplike publikasies in ingenieurswese in Suid-Afrika. 


\section{INTRODUCTION}

The significance of engineering science to the economy - and its relation to the development of a country - is widely acknowledged [1, 2]. More importantly, engineering research provides the impetus for the growth of a nation. Research in any field of science is manifest in the production of scientific publications. Scientific publications therefore offer insight into trends and directions within the discipline.

Studies have investigated trends in engineering research, as shown in the publications stored in different databases for varying periods of time [3-9]. Some have explored the collaborative dimensions hidden in such scientific publications [10-12]. As far as South African engineering research is concerned, there are a few relevant studies. Sooryamoorthy [9], making a pioneering attempt, provides a bibliometric analysis of the trends and patterns of South African engineering research since 1975. Another study on the visibility of engineering publications, which appeared in the South African Journal of Industrial Engineering, has examined the visibility of South African engineering research as measured by the number of citations that engineering publications received [8]. This study showed how the visibility of South African engineering research is determined by certain key variables. Mouton [12] noted the relative absence of collaboration across disciplines and institutions in South Africa. Unlike these studies, this paper is the first attempt to investigate collaboration in engineering research over a longer period. The key objective of this paper is to examine the relation between the production of scientific papers and collaboration, and to see how collaboration affects the production of publications (or vice versa). In other words, it is of interest to investigate whether the observed features of scientific publications in engineering are related to the collaborative efforts - domestic and international - of South African engineers.

\section{DATA AND METHODS}

The analysis presented in this paper is based on the data drawn in several stages from the ISI Web of Knowledge, the Science Citation Index Expanded (1945-present). An appropriate period was first chosen. From 1945 to 1965, no papers by South African scholars were in the database, either because they were not publishing or because they not yet begun to appear in the SCl journals [13]. Until 1971 only a few publications were recorded in the ISI; thereafter the number of publications began to increase. The year 1975 thus presents itself as the best starting point, followed by another sample year for every five subsequent years. The data for a three-decade period, with representative years of 1975, 1980, 1985, 1990, 1995, 2000, and 2005, were retrieved for this analysis.

The types of publications to be analysed were selected in the second stage. Publications grouped as 'articles' and 'reviews' for the chosen years were collected. These articles and reviews had a minimum of one South African author in the publication records. There were 18,466 such publications by South African authors and their partners in the seven selected years, of which 2,036 belonged to the field of engineering.

The subject of each publication was then determined. This being a study of engineering publications by South Africans, all the engineering publications listed in the subject category of the ISI records were gathered. The subject category of engineering included publications in engineering, computer science, crystallography, instrumentation, materials science, mineralogy, remote sensing, transportation, and medical technology. For the classification and inclusion of the different branches of engineering, the system of classification developed by the Centre for Research on Science and Technology at Stellenbosch University was adopted [14]. All the basic details of the publication records from the database were collected and entered manually into a statistical software programme for further analysis. 


\section{RESULTS}

\subsection{Publications in engineering}

Table 1 presents the characteristics of publications in engineering produced by South African authors. For all the selected years from 1975 to 2005 the average number of authors per publication was 2.48. This ranged between 1.78 (in 1980) and 2.93 (in 2005), showing a progressively upward trend over the selected years. An average of 1.27 countries per publication was found among the international publications that brought together authors from overseas. The lowest value of 1.06 countries per international publication was reported in 1985. In 2005 this average rose to 1.34 .

\begin{tabular}{|c|c|c|c|c|c|c|c|c|c|c|c|c|c|c|c|c|}
\hline \multirow{3}{*}{ Publications } & \multicolumn{14}{|c|}{ Year } & & \\
\hline & \multicolumn{2}{|c|}{$1975(\mathrm{~N}=86)$} & \multicolumn{2}{|c|}{$\begin{array}{c}1980 \\
(N=201)\end{array}$} & \multicolumn{2}{|c|}{$\begin{array}{c}1985 \\
(N=222)\end{array}$} & \multicolumn{2}{|c|}{$\begin{array}{c}1990 \\
(N=244)\end{array}$} & \multicolumn{2}{|c|}{$\begin{array}{c}1995 \\
(N=359)\end{array}$} & \multicolumn{2}{|c|}{$\begin{array}{c}2000 \\
(N=350)\end{array}$} & \multicolumn{2}{|c|}{$\begin{array}{c}2005 \\
(\mathrm{~N}=574)\end{array}$} & \multicolumn{2}{|c|}{$\begin{array}{c}\text { All } \\
(\mathrm{N}=2036)\end{array}$} \\
\hline & $\frac{\widetilde{\varpi}}{\Sigma}$ & Q & $\begin{array}{l}\frac{\pi}{0} \\
\sum \\
\sum\end{array}$ & Q & $\begin{array}{l}\frac{\pi}{0} \\
\sum \\
\sum\end{array}$ & n & 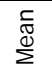 & h & 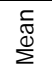 & h & 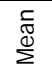 & Q & $\begin{array}{l}\frac{1}{0} \\
\frac{\mathbb{N}}{2}\end{array}$ & $a$ & $\begin{array}{l}\complement \\
\mathbb{0} \\
\sum\end{array}$ & कि \\
\hline \multirow{3}{*}{$\begin{array}{l}\text { No. of authors/ publn } \\
\text { No. of foreign } \\
\text { countries/ international } \\
\text { publn }\end{array}$} & 1.8 & 0.9 & 1.8 & 1.0 & 2.0 & 1.1 & 2.2 & 1.3 & 2.5 & 1.5 & 2.8 & 2.5 & 2.9 & 2.3 & 2.5 & 1.9 \\
\hline & 1.1 & 0.4 & 1.1 & 0.4 & 1.1 & 0.2 & 1.1 & 0.4 & 1.2 & 0.5 & 1.3 & 1.0 & 1.3 & 1.2 & 1.3 & 0.9 \\
\hline & $\mathrm{N}$ & $\%$ & $\mathrm{~N}$ & $\%$ & $\mathrm{~N}$ & $\%$ & $\mathrm{~N}$ & $\%$ & $\mathrm{~N}$ & $\%$ & $\mathrm{~N}$ & $\%$ & $\mathrm{~N}$ & $\%$ & $\mathrm{~N}$ & $\%$ \\
\hline Sole authored papers $* * *$ & 38 & 44.2 & 100 & 49.8 & 86 & 38.7 & 78 & 32.0 & 71 & 19.8 & 64 & 18.3 & 107 & 18.6 & 544 & 26.7 \\
\hline $\begin{array}{l}\text { Coauthored papers*** } \\
\text { All South African }\end{array}$ & 48 & 55.8 & 101 & 50.2 & 136 & 61.3 & 166 & 68.0 & 288 & 80.2 & 286 & 81.7 & 467 & 81.4 & 1492 & 73.3 \\
\hline $\begin{array}{l}\text { authors*** \# } \\
\text { SA authors within the }\end{array}$ & 40 & 83.3 & 86 & 85.1 & 101 & 74.3 & 138 & 83.1 & 216 & 75.0 & 175 & 61.2 & 279 & 59.7 & 1035 & 69.4 \\
\hline same organ***a\#\& & 35 & 72.9 & 17 & 37.8 & 22 & 30.1 & 22 & 34.4 & 31 & 20.7 & 233 & 81.5 & 379 & 81.3 & 739 & 65.2 \\
\hline Any collaboration & 48 & 55.8 & 101 & 50.2 & 136 & 61.3 & 166 & 68.0 & 288 & 80.2 & 286 & 81.7 & 467 & 81.4 & 1492 & 73.3 \\
\hline $\begin{array}{l}\text { Domestic collaboration\# } \\
\text { Internal institutional }\end{array}$ & 41 & 85.4 & 86 & 85.1 & 101 & 74.3 & 138 & 83.1 & 218 & 75.7 & 184 & 64.3 & 300 & 64.2 & 1068 & 71.6 \\
\hline $\begin{array}{l}\text { collaboration\# } \\
\text { External institutional }\end{array}$ & 36 & 75.0 & 75 & 74.3 & 85 & 62.5 & 122 & 73.5 & 167 & 58.0 & 133 & 46.5 & 221 & 47.3 & 839 & 56.2 \\
\hline $\begin{array}{l}\text { collaboration\# } \\
\text { International }\end{array}$ & 5 & 10.4 & 12 & 11.9 & 17 & 12.5 & 17 & 10.2 & 53 & 18.4 & 53 & 18.5 & 88 & 18.8 & 245 & 16.4 \\
\hline $\begin{array}{l}\text { collaboration\# } \\
\text { Multi-country } \\
\text { international }\end{array}$ & 8 & 16.7 & 15 & 14.9 & 35 & 25.7 & 27 & 16.3 & 71 & 24.7 & 111 & 38.8 & 188 & 40.3 & 455 & 30.5 \\
\hline collaboration & 1 & 2.1 & 2 & 2.0 & 2 & 1.5 & 2 & 1.2 & 12 & 4.2 & 21 & 7.3 & 37 & 7.9 & 77 & 5.2 \\
\hline
\end{tabular}

Notes: ***, **, * significant at the $.01, .05, .1$ levels respectively. a. Chi-square test; \# If refers to single authored paper they are not applicable under this classification. \# percentage out of 'any collaboration'; \$ percentage out of 'international collaboration'; \& excludes international collaboration; S.D. is Standard Deviation.

\section{Table 1: Publications in engineering in South Africa, 1975-2005}

Of the 2,036 publications, 544 (27\%) were sole-authored, while the remaining 1,492 (73\%) were produced in collaboration either with other South African authors or with international partners. In 1980 half of the papers were sole-authored, but this dropped to $18 \%$ in 2000 . On the other hand, co-authored publications increased from $50 \%$ to $82 \%$ Among all the coauthored papers for the whole period of analysis, $70 \%$ of the papers belonged to South African authors $(1,035$ out of 1,492). Year-wise analysis shows that the percentage of South African authors in co-authored publications shrank from $83 \%$ in 1975 to $60 \%$ in 2005 . In $65 \%$ of the papers (of those produced by South African authors only) the authors belonged to the same department or institution.

In terms of collaboration, publications can be classified into collaborated (co-authored) and non-collaborated (sole-authored) papers. Collaboration happens at the domestic level when authors are from within the country, or at the international level when at least one author joins from overseas. Domestic collaboration is further bifurcated into internal-institutional 
(authors belonging to the same department or institution within South Africa) and externalinstitutional (authors from different institutions in South Africa).

Out of the total of 2,036 papers produced during the period of analysis, 1,492 (73\%) were collaborated papers. The proportion of collaborated papers was $56 \%$ in 1975; by 2005 it had increased to $81 \%$ Domestic collaboration was found in 1,068 papers $(72 \%)$ of the collaborated papers for the whole period. After 1975, the percentage of collaborated papers at the domestic level decreased from $85 \%$ in 1975 to $64 \%$ in 2005 . Internalinstitutional collaboration was evident in $56 \%$ while external-institutional collaboration formed $16 \%$ of the domestic collaborated papers. Variation within years was seen in both types of domestic collaboration. The papers produced in internal-institutional collaboration declined from $75 \%$ in 1975 to $47 \%$ in 2005 . On the other hand, external-institutional collaboration grew from $10 \%$ in 1975 to $19 \%$ in 2005.

Collaboration that involved overseas partners was found in one-third of the publications with any kind of collaboration. In 1975 the proportion of internationally collaborated papers was $17 \%$ as against $40 \%$ in 2005 . Multi-country collaboration - in which more than one foreign country was involved - comprised $5 \%$ of the total international publications. This category of international collaboration also expanded from 2\% in 1975 to 8\% in 2005.

\subsection{Production and collaboration}

Having presented the features of South African publications in engineering, the question now is whether the production of scientific papers is related to the collaboration of scientists, domestic or international. In other words, has collaboration led to a change in the number of publications by South African engineers? If so, collaboration has influenced the production of scientific research in engineering.

Table 2 compiles four relevant variables that illustrate the influence of collaboration in engineering: the total number of publications, and collaborated papers (all, domestic, and international). All of these are further classified according to number, growth or decline over the first year of analysis (1975), and the change (positive or negative) over the year immediately before. In collaborated papers another sub-variable shows their percentage of the total engineering publications.

In the total tally of papers, the number rose from 86 to 574 over three decades (Table 2, col.2). The average year-on-year change was thus $95 \%(1975=100)$ (col.4, row 8). Collaborated publications in engineering grew from 48 to 467 . This can be viewed from two different standpoints: (1) its proportion to the total number of publications; and (2) the increase/ decrease within collaboration for the period.

In the first count, collaborated papers grew from $56 \%$ to $81 \%$ (col.8), with an average fiveyearly change of 4.27 percentage points (row 8, col.9). In the second count, collaborated papers had an average year-on-year growth of $146 \%(1975=100$; col.7, row 8$)$. This suggests that collaborated papers had a higher rate of growth than the total number of papers in engineering. Going beyond this, it is important to see the changes that occurred in domestic and international collaboration. Domestically collaborated papers showed an average change of $105 \%$ during the period (row 8, col.12). However, the percentage of papers to the total number of papers contracted from $85 \%$ to $64 \%$ with an average of $74 \%$ (col.13); and the mean year-on-year change was negative for the period (-3.53, row 8, col.13). International collaboration, as against domestic collaboration, reached a record high average change of $375 \%$ for every five years (row 8 , col. 17). But the proportion of internationally collaborated papers to the total number of publications declined from 75\% to 47\% between 1975 and 2005 , with an average change of $4.62 \%$ In sum, the year-on-year change was $95 \%$ for all papers in engineering, $146 \%$ for all collaborated papers, $105 \%$ for papers produced in domestic collaborative research, and $375 \%$ for internationally collaborated papers. Clearly, collaborated papers expanded at a faster pace than the total number of papers published in engineering science. This is graphically illustrated in Fig. 1. 


\begin{tabular}{|c|c|c|c|c|c|c|c|c|c|c|c|c|c|c|c|c|c|c|}
\hline \multirow[t]{2}{*}{ Year } & \multicolumn{3}{|c|}{$\begin{array}{l}\text { Engineering } \\
\text { publications }\end{array}$} & \multicolumn{5}{|c|}{$\begin{array}{l}\text { Collaborated } \\
\text { Publications }\end{array}$} & \multicolumn{5}{|c|}{$\begin{array}{c}\text { Domestic } \\
\text { collaboration papers }\end{array}$} & \multicolumn{5}{|c|}{$\begin{array}{c}\text { International } \\
\text { collaboration papers }\end{array}$} \\
\hline & $z$ & 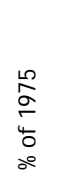 & 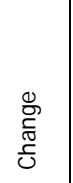 & $z$ & 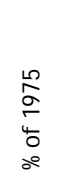 & $\begin{array}{l}\mathscr{g} \\
\bar{\sigma} \\
\frac{\sigma}{U}\end{array}$ & $\begin{array}{l}\frac{1}{0} \\
\frac{0}{3} \\
\frac{0}{0} \\
0 \\
\frac{1}{4} \\
\text { प⿺ } \\
\frac{0}{0}\end{array}$ & $\begin{array}{l}\frac{g}{c} \\
\frac{\sigma}{\delta} \\
\frac{\delta}{U}\end{array}$ & $z$ & 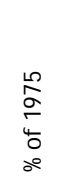 & $\begin{array}{l}\frac{y}{0} \\
\frac{0}{0} \\
\frac{c}{U}\end{array}$ & $\begin{aligned} & \frac{n}{0} \\
& \frac{0}{2} \\
& \frac{0}{0} \\
& 4 \\
& \frac{0}{0} \\
& \circ\end{aligned}$ & $\begin{array}{l}\mathscr{0} \\
\frac{0}{\sigma} \\
\frac{\pi}{U}\end{array}$ & z & 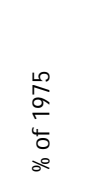 & 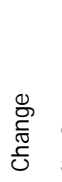 & 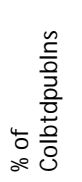 & $\begin{array}{l}\mathscr{\emptyset} \\
\frac{c}{\sigma} \\
\frac{\tilde{U}}{U}\end{array}$ \\
\hline 1 & 2 & 3 & 4 & 5 & 6 & 7 & 8 & 9 & 10 & 11 & 12 & 13 & 14 & 15 & 16 & 17 & 18 & 19 \\
\hline 1975 & 86 & 100.0 & & & 100.0 & & 55.8 & & 41 & 100 & & 85.4 & & 36 & 100 & & 75 & \\
\hline 1980 & 201 & 233.7 & 133.7 & 101 & 210.4 & 110.4 & 50.2 & -5.6 & 86 & 209.71 & 109.8 & 385.1 & -0.3 & 75 & 187.5 & 87.5 & 74.3 & 0.7 \\
\hline 1985 & 222 & 258.1 & 24.4 & 136 & 283.3 & 72.9 & 61.31 & 11.1 & 101 & 246.3 & 36.6 & $574.3-$ & 10.8 & 85 & 437.5 & 250 & 62.51 & 11.8 \\
\hline 1990 & 244 & 283.7 & 25.6 & 166 & 345.8 & 62.5 & 68 & 6.7 & 138 & 336.6 & 90.2 & 283.1 & 8.8 & 122 & 337.5 & -100 & 73.5 & -11 \\
\hline 1995 & 359 & 417.4 & 133.7 & 288 & 600.0 & 254.2 & 80.21 & 12.2 & 218 & 531.71 & 195.1 & 175.7 & -7.4 & 167 & 887.5 & 550 & & 15.5 \\
\hline 2000 & 350 & 407.0 & -10.5 & 286 & 595.8 & -4.2 & 81.7 & 1.5 & 184 & 448.8 & -82.9 & $964.3-$ & 11.4 & 133 & 1387.5 & 500 & 46.51 & 11.5 \\
\hline 2005 & 574 & 667.4 & 260.5 & 467 & 972.9 & 377.1 & 81.4 & -0.3 & 300 & 731.72 & 282.9 & 964.2 & -0.1 & 221 & 235.09 & 362.5 & 47.3 & -0.8 \\
\hline Avge & 254.8 & 296.3 & 94.6 & 240.7 & 501.4 & 145.5 & 70.5 & 4.3 & 171.2 & 417.51 & 105.3 & 374.5 & -3.5 & 133.8 & 931.33 & 375.0 & 60.34 & 4.6 \\
\hline
\end{tabular}

Table 2: Publication and collaboration in South African engineering, 1975-2005

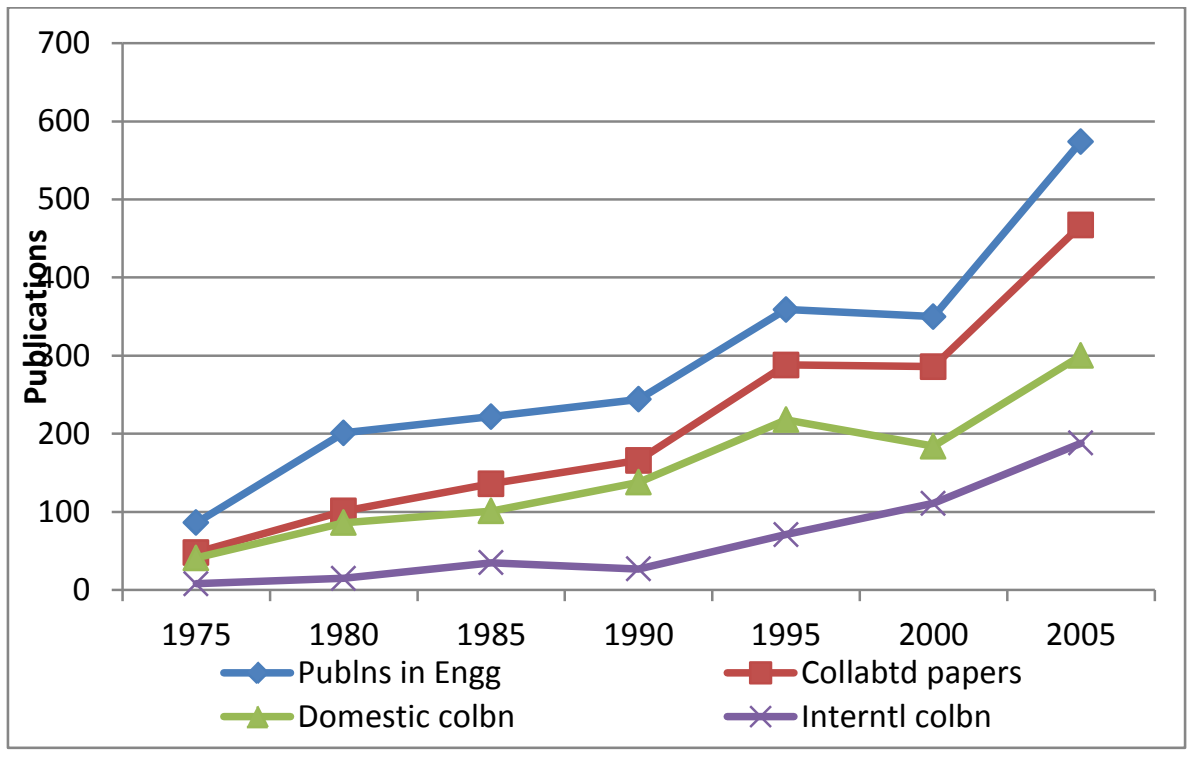

Figure 1: Publication and collaboration in South African engineering, 1975-2005 


\subsection{Predicting collaboration}

The observed relationship between collaboration and publication needs to be examined further to find out how collaboration determines the number of publications in engineering. Table 3 presents the correlation coefficients of some key variables. As the coefficients indicate, the degree of collaboration was significantly correlated with the year of publication, the number of authors (log converted) per publication, the presence of all South Africans, South Africans in the same organisation, number of citations received (log converted), publications in non-local journals, and the number of countries (log converted) that participated in the production of papers. The correlation coefficients are negative in most cases. The year in which the papers were published is negatively related to the degree of collaboration. That is, the earlier the year of publication, the lower the degree of collaboration. This finding corroborates the earlier result that collaboration in engineering has been improving from the first year of analysis (1975). The number of authors and the degree of collaboration are clearly related: the greater the number of authors, the more intense the collaboration. The connection between the degree of collaboration and the authors who are all South Africans, or who are from the same organisation, does not provide substantial evidence.

The number of citations received by the publications in engineering is decisively related to collaboration, as the positive correlation of these variables shows. Publications that appeared in foreign journals, however, do not affect the degree collaboration, as they are negatively correlated. Meanwhile the number of countries has a definite positive relationship with the degree of collaboration.

\begin{tabular}{|c|c|c|c|c|c|c|c|}
\hline 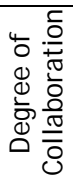 & 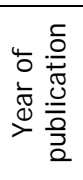 & 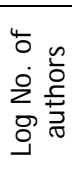 & 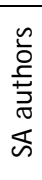 & 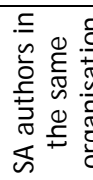 & 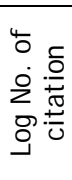 & 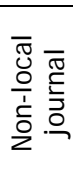 & 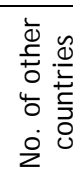 \\
\hline
\end{tabular}

\begin{tabular}{lcccccccc}
\hline Degree of collabortion & 1 & & & & & & \\
Year of publication & $-0.054^{* *}$ & 1 & & & & & \\
Log No. of authors & $0.734^{* * *}$ & $0.012 \mathrm{~ns}$ & 1 & & & & \\
SA authors & $-0.417^{* * *}$ & $-0.241^{* * *}$ & $-0.418^{* * *}$ & 1 & & & \\
SA authors in the same & & & & & & & \\
organization & $-0.232^{* * *}$ & $0.163^{* * *}$ & $-0.127^{* * *}$ & $-0.201^{* * *}$ & 1 & & \\
Log No. of citation & $0.08^{* *}$ & $-0.353^{* * *}$ & $0.095^{*}$ & $-0.03 \mathrm{~ns}$ & $-0.046^{*}$ & 1 & \\
Non-local journal & $-0.047^{*}$ & $0.065^{* *}$ & $-0.024 \mathrm{~ns}$ & $0.064^{* *}$ & $0.076^{* *}$ & $0.044^{*}$ & 1 \\
No. of other countries & $0.481^{* * *}$ & $0.177^{* * *}$ & $0.524^{* * *}$ & $-0.718^{* * *}$ & $0.125^{* * *}$ & $0.039^{*}$ & $-0.065^{* *}$ & 1 \\
\hline
\end{tabular}

Significance: $* *=.05 ; *=1, * * *=.001, \mathrm{~ns}=$ non-significant.

\section{Table 3: Correlation matrix of the degree of collaboration in engineering and other variables}

Continuing with the analysis, as seen in Table 4, three models of the regression of collaboration on selected independent variables were run. Model 1 explains how the degree of collaboration can be predicted while controlling for the year of publication, the number of authors, the presence of all South African authors, and authors belonging to the same organisation, the number of citations, publications in non-local journals, and the number of countries involved in the production of papers. This model explains $59 \%$ of variance $\left(R^{2}=596\right)$ with all these control variables. In agreement with the correlation analysis (Table 3 ), the degree of collaboration in this model is positively related to the number of authors and countries involved in publications in engineering. A number of other variables - such as the year of publication, and the presence of South African authors within the same organisation - are negatively associated. It appears that neither the papers published in 
non-local journals nor the number of citations changes the degree of collaboration in engineering in South Africa.

\begin{tabular}{|c|c|c|c|c|c|c|}
\hline & 1 & & 2 & & 3 & \\
\hline $\begin{array}{l}\text { Publication } \\
\text { attributes }\end{array}$ & $\begin{array}{l}\text { Degree } \\
\text { of } \\
\text { collabo- } \\
\text { ration }\end{array}$ & Sig & $\begin{array}{l}\text { Domestic } \\
\text { Collabo- } \\
\text { ration }\end{array}$ & Sig & $\begin{array}{l}\text { Interna- } \\
\text { tional } \\
\text { Collabo- } \\
\text { ration }\end{array}$ & Sig \\
\hline Year publication appeared & -0.097 & 0.000 & -0.004 & 0.799 & 0.001 & 0.833 \\
\hline Log number of authors & 0.597 & 0.000 & 0.064 & 0.000 & 0.012 & 0.000 \\
\hline $\begin{array}{l}\text { All South African authors ( } 1=y e s, \\
0=\text { others) }\end{array}$ & -0.161 & 0.000 & 0.896 & 0.000 & -0.991 & 0.000 \\
\hline $\begin{array}{l}\text { SA authors in the same organization } \\
\text { (1=yes, } 0=\text { others) }\end{array}$ & -0.186 & 0.000 & -0.105 & 0.000 & 0.002 & 0.512 \\
\hline Log number of citation & -0.028 & 0.163 & -0.02 & 0.132 & -0.002 & 0.51 \\
\hline $\begin{array}{l}\text { Publications appeared in non-local } \\
\text { journals ( } 1=y e s, 0=\text { others) }\end{array}$ & 0.005 & 0.778 & -0.001 & 0.914 & -0.002 & 0.401 \\
\hline No. of other countries involved & 0.094 & 0.001 & -0.023 & 0.222 & -0.002 & 0.585 \\
\hline R2 & 0.596 & & 0.859 & & 0.991 & \\
\hline $\mathrm{N}$ & 1149 & & 978 & & 1148 & \\
\hline
\end{tabular}

Note: Degree of collaboration index on a continuum of 0-4.

Table 4: Regression of publications in engineering on collaboration

The second model that predicts domestic collaboration emerges with a higher variance of $85 \%\left(R^{2}=856\right)$ with two positively associated variables of the number of authors and the presence of all South African authors. All other variables are either negatively associated or insignificant. It means that the likelihood of domestic collaboration can be predicted by the presence of the number of authors and whether these authors are from within South Africa.

International collaboration, as seen in model 3, can be explained by knowing the values of certain independent variables. The number of authors is positively related, while understandably - the presence of South African authors is negatively related. The standardised beta coefficients of all other variables are not statistically significant in explaining the presence of international collaboration in engineering science in South Africa.

\section{DISCUSSION}

Apart from examining the characteristic features of scientific publications of South Africans and their partners in the field of engineering over 30 years, the key question this study sought to answer was whether the production of scientific research in engineering science in South Africa is related to collaboration, both within and outside the borders of the country. The analysis of relevant variables showed that collaborated papers in engineering grew at a faster pace than all of the papers taken together. Expressed differently, collaborated publications in general, irrespective of type - domestic or international - changed more than the total number of publications. The evidence therefore supports the conclusion that collaboration has influenced the production of engineering publications in South Africa. The correlation analysis of the degree of collaboration and other variables proved that collaboration is determined by the year of publication (it has expanded in recent years, and might maintain this trend in future), the number of authors (as the number of authors who do combined research increases, collaboration is strengthened), the choice of publication outlets (whether these are local or non-local) does not influence the degree of collaboration, and the number of countries that participate produces a commensurate change in the degree of collaboration. Regression analyses revealed more auxiliary information on the dimensions of collaboration in engineering. On the basis of these models, 
one could predict the degree of collaboration, domestic collaboration, and international collaboration in engineering science in South Africa. This finding might be unique to engineering. A similar study of the publications in medicine in South Africa showed that publication did not increase in relation to collaboration ${ }^{13}$. However, Mouton (2000) found a moderate positive correlation between multiple authorship and scientific output of South African researchers [12]. But publications resulting from scientific research, as Kundra and Kretschmer (1999) reported, cannot be explained solely in terms of collaboration [16]. The literature on scientific partnerships abounds in empirical evidence that supports (or rejects) the two-way relationship between productivity and collaboration. Chen et al. (2007) and Navarro and Martin (2004) both noted an inverse relationship between these two variables $[17,18]$. Basu and Aggarwal (2001) found that international collaboration is increasing the output of Indian science ${ }^{17}$. Glānzel et al. (1999) and Wagner (2005) have also considered this issue in detail $[20,21]$.

\section{CONCLUSIONS}

South Africa has made significant strides in engineering. Its track record is partly attributed to the country's response to the demands of its major industries such as the mining of diamonds, gold, and coal [22]. Rooks et al. (2005) reported that South Africa's profile in engineering is comparable to that of France, Belgium, and Spain [23]. As shown in the analysis above, the production of scientific publications in engineering in South Africa has been steadily progressing. Importantly, the collaborative dimensions of South African engineers are clearly evident in this analysis. They prefer to work in teams rather than individually, and are inclined to collaborate with scholars from overseas. As collaboration has turned out be a decisive factor in the production of papers in engineering, joint endeavours in engineering research should be encouraged. This will have a positive impact on the growth of the discipline and on the economy of South Africa. Evidence suggests that publications originating from collaboration yield relatively more citations and have more impact than sole-authored publications [24-28].

\section{ACKNOWLEDGEMENT}

This material is based upon work supported financially by the National Research Foundation.

\section{REFERENCES}

[1] Bengisu, M. 2003. Critical and emerging technologies in materials, manufacturing, and industrial engineering: A study of priority setting, Scientometrics, 58(3), pp. 473-487.

[2] Lister, G. \& Donaldson, K. 2003. New roles for industrial engineers in developing countries, South African J ournal of Industrial Engineering, 15(1), pp. 43-52.

[3] Arvanitis, R., Waast, R. \& Gaillard, J. 2000. Science in Africa: A bibliometric panorama using PASCAL database, Scientometrics, 47(3), pp. 457-473.

[4] Tsay, M-Y. 2009. An analysis and comparison of scientometric data between journals of physics, chemistry and engineering, Scientometrics, 78(2), pp. 279-293.

[5] Dastidar, P.G. \& Ramachandran, S. 2005. Engineering research in ocean sector: An international profile, Scientometrics, 65(2), pp. 199-213.

[6] Rao, I.K.R. \& Suma, P. 1999. A quantitative study of Indian engineering literature, Scientometrics, 46(3), pp. 605-619.

[7] Pouris, A. 2009. Quantitative assessment of South Africa's inventive outputs: International patent analysis, South African J ournal of Industrial Engineering, 20(1), pp 13-29.

[8] Sooryamoorthy, R. 2010. The visibility of engineering research in South Africa, South African J ournal of Industrial Engineering, 21(2), pp. 1-12.

[9] Sooryamoorthy, R. 2010. Scientific publications of engineers in South Africa, 1975-2005, Scientometrics, 86(1), pp. 211-226.

[10] Boshoff, N. 2009. South-South research collaboration of countries in the Southern African Development Community (SADC), Scientometrics, 84(2), pp. 481-503.

[11] Abramo, G., D'Angelo, C.A. \& Costa, F.D. 2009. Research collaboration and productivity: Is there correlation? Higher Education, 57, pp. 155-171.

[12] Mouton, J. 2000. Patterns of research collaboration in South Africa. South African J ournal of Science, 96(9/ 10), pp. 458-462. 
[13] Sooryamoorthy, R. 2009. Collaboration and publication: How collaborative are scientists in South Africa?, Scientometrics, 80(2), pp. 419-439.

[14] Boshoff, N. 2009. Neo-colonialism and research collaboration in Central Africa, Scientometrics, 81(2), pp. 413-434.

[15] Sooryamoorthy, R. 2010. Medical research in South Africa: A scientometric analysis of trends, patterns, productivity and partnership, Scientometrics, 84(3), pp. 863-885.

[16] Kundra, R. \& Kretschmer, H. 1999. A new model of scientific collaboration: Part 2, Collaboration patterns in Indian medicine, Scientometrics, 46(3), pp. 519-528.

[17] Chen, T-J., Chen, Y-C., Hwang, S-J. \& Chou, L.F. 2007. International collaboration of clinical medicine research in Taiwan, 1990-2004: A bibliometric analysis, Journal of Chinese Medical Association, 70(3), pp. 110-116.

[18] Navarro, A. \& Martin, M.2004. Scientific production and international collaboration in occupational health, 1992-2001, Scandinavian J ournal of Work, Environment and Health, 30(3), pp. 223-233.

[19] Basu, A. \& Aggarwal, R. 2001. International collaboration in science in India and its impact on institutional performance, Scientometrics, 52(3), pp. 379-394.

[20] Glānzel, W., Schubert, A. \& Czerwon, H.J. 1999. A bibliometric analysis of international scientific cooperation of the European Union (1985-1995), Scientometrics, 45(2), pp. 185-202.

[21] Wagner, C.S. 2005. Six case studies of international collaboration in science, Scientometrics, 62(1), pp 3-26.

[22] SAJ S. 2006. Engineering the future. South African J ournal of Science, 102(11\&12), p. 506.

[23] Rooks, G., Oerlemans, L., Buys, A. \& Pretorius, T. 2005. Industrial innovation in South Africa: A comparative study, South African J ournal of Science, 101(3\&4), pp. 149-150.

[24] Sooryamoorthy, R. 2009. Do types of collaboration change citation? Collaboration and citation patterns of South African science publications, Scientometrics, 81(1), pp. 171-193.

[25] Schmoch, U. \& Schubert, T. 2008. Are international co-publications an indicator for quality of scientific research?, Scientometrics, 74(3), pp. 361-377.

[26] Ma, N. \& Guan, J . 2005. An exploratory study on collaboration profiles of Chinese publications in molecular biology, Scientometrics, 65(1), pp. 343-355.

[27] Gupta, B.M. \& Karisiddippa, C.R. 1999. Collaboration and author productivity: A study with a new variable in Lotka's Law, Scientometrics, 44(1), pp. 129-134.

[28] Moed, H.F. \& Hesselink, F.T. 1996. The publication output and impact of academic chemistry research in the Netherlands during the 1980s: Bibliometric analyses and policy implications, Research Policy, 25(5), pp. 819-836. 